\title{
MECHANISMS OF KARST BREAKDOWN FORMATION IN THE GYPSUM KARST OF THE FORE-URAL REGION, RUSSIA (FROM OBSERVATIONS IN THE KUNGURSKAJA CAVE)
}

\author{
Vjacheslav ANDREJCHUK and Alexander KLIMCHOUK
}

\begin{abstract}
The fore-Ural is a classical region of intrastratal gypsum karst. The intensive development of karst in the Permian gypsums and anhydrites causes numerous practical problems, the subsidence hazard being the most severe.

Mechanisms of karst breakdown formation were studied in detail in the Kunguskaya Cave area. The cave and its setting are characteristic to the region and, being a site of detailed stationary studies for many years, the cave represents a convenient location for various karst and speleological investigations.

Breakdown structures related to cavities of the Kungurskaya Cave type develop by two mechanisms: gravitational (sagging and fall-in of the ceilings of cavities) and filtrational/gravitational (crumbling and fall-in of the ceilings of vertical solution pipes, facilitated by percolation). The former implies upward stoping of the breakout roof and cessation of the process at some height above the floor of the cave due to complete infilling by fallen clasts. This mechanism cannot generate surface deformation where the overburden thickness exceeds a certain value. The latter mechanism implies that breakdown will almost inevitably express itself at the surface, most commonly as a sudden collapse, even where the thickness of the overburden is large. These mechanisms result in different appearance, distribution and further evolution of the respective surface forms, so that subsidence hazard assessment should be performed differently for these types of breakdown.

The conclusions reached by this study are representative for the region, although some of them bear more general validity for intrastratal karst conditions. This study underlines the ultimate importance of speleological investigations to the understanding of karst breakdown mechanisms.
\end{abstract}

KEYWORDS: gypsum karst, karst subsidence, subsidence hazard, cave breakdown, speleogenesis, Ural region.

\section{Introduction}

Aimed at characterization and understanding of subsidence phenomena and underlying karst breakdown processes in the fore-Ural region, this study also seeks to contrast these with another well-known region of gypsum karst, the Western 
Ukraine (see Klimchouk and Andrejchuk, this volume). Subsidence phenomena are widespread in both regions, and comparing them can help to reveal specific and general features. Like the Western Ukraine, the fore-Ural region is located on the margin of the craton (the eastern limit of the Eastern European Platform), in the zone of its junction with the foreland structure of a large folded region (the Ural Mountains), the Ural Foredeep. The sulphate karst in the fore-Ural develops in gypsum and anhydrite beds of the Lower Permian evaporitic sequence, which spreads through both the platform margin and the foredeep. Besides similarities in the lithology of the karstifiable rocks and their geostructural position, the two regions have some other features in common. Both display temperate climatic conditions and transitional forestto-steppe landscape, the subhorizontal or monoclinal occurrence of the soluble beds, and the presence of a loose sediment cover of variable thickness.

Equally, there are also substantial differences between the conditions of gypsum karst development in the Western Ukraine and the fore-Ural regions (Andrejchuk, 1996; Andrejchuk and Klimchouk, 1996), which determine some specific aspects of subsidence phenomena and processes in the two regions. In particular, these differences appear in:

- The nature and character of the fissuring in the sulphate strata (prevalence of vertical fissures arranged in superimposed networks confined to particular horizons of the gypsum bed in the Western Ukraine, versus complex polygenetic networks in the fore-Ural);

- Density and permeability of fissure networks (lower and more anisotropic in the Western Ukraine versus higher and more isotropic in the fore-Ural);

- The age of karstification (Pliocene-Pleistocene in the Western Ukraine versus Mesosoic-Cenosoic, polycyclic in the fore-Ural);

- The thickness and lithostratigraphy of the karstifiable strata (10 to 40m-thick single gypsum bed in the Western Ukraine, versus 60 to $90 \mathrm{~m}$-thick interbedded sequence of gypsum, anhydrite and dolomite in the fore-Ural);

- The nature of the overburden (low permeability clays in the Western Ukraine versus a freely permeable breccia horizon and loose loamy sediments in the foreUral);

- The structure of the sulphate rocks (recrystallized, predominantly coarsely-crystalline, gypsum in the Western Ukraine versus micro- and crypto-crystalline gypsum and anhydrite in the fore-Ural).

- The history of karst development (the karst in the Western Ukraine has evolved since the Pliocene in one major phase of uplift. In the fore-Ural, continental conditions were established during the Mesozoic, and the region has experienced repeated oscillations of tectonic movement, resulting in repeated overdeepening of river valleys and subsequent changes in the conditions of karst development).

Breakdown development mechanisms have been studied in detail in Kungurskaya Cave, the largest gypsum cave in the region (Fig.1). The cave developed in conditions typical of the fore-Ural, and the pattern and morphology represent well the style of underground karstification of sulphate massifs in the region. Hence, the general conclusions inferred from this study can reasonably be extended to most of the foreUral gypsum karst, at least to the zone of entrenched and subjacent karst. 
The Kungurskaya Cave is well-suited for detailed studies of mechanisms of breakdown formation. It is easily accessible and horizontal, and consists of passages and chambers of considerable size. It has permanent lighting as it is used as a show cave (Dorofeev and Andrejchuk, 1990). The massif in which the cave is developed is well documented geologically and hydrogeologically. The breakdown structures, occurring widely in the cave, represent different types and stages of development.

\section{The Kungurskaya Cave and settings of karst breakdown development}

The cave lies in the Perm administrative region, on the northern outskirts of Kungur town. The area belongs to the north-west margin of the Ufimsky Plateau, with elevations ranging from 300 to $400 \mathrm{~m}$ asl. The plateau surface is entrenched for 50 to $150 \mathrm{~m}$ by river valleys (Fig.2), which separate the gypsum/anhydrite sequence into numerous interfluve massifs.

\section{1. Geomorphological and geological settings}

Historically the massif in which the Kungurskaya Cave is developed is known as the Ice Mountain, because the entrance series of the cave contains ice formations during all seasons. The Ice Mountain represents an elevated plateau-like massif (about $10 \mathrm{~km}^{2}$ ) bounded by the valleys of the Sylva River and its tributary, the Shakva River

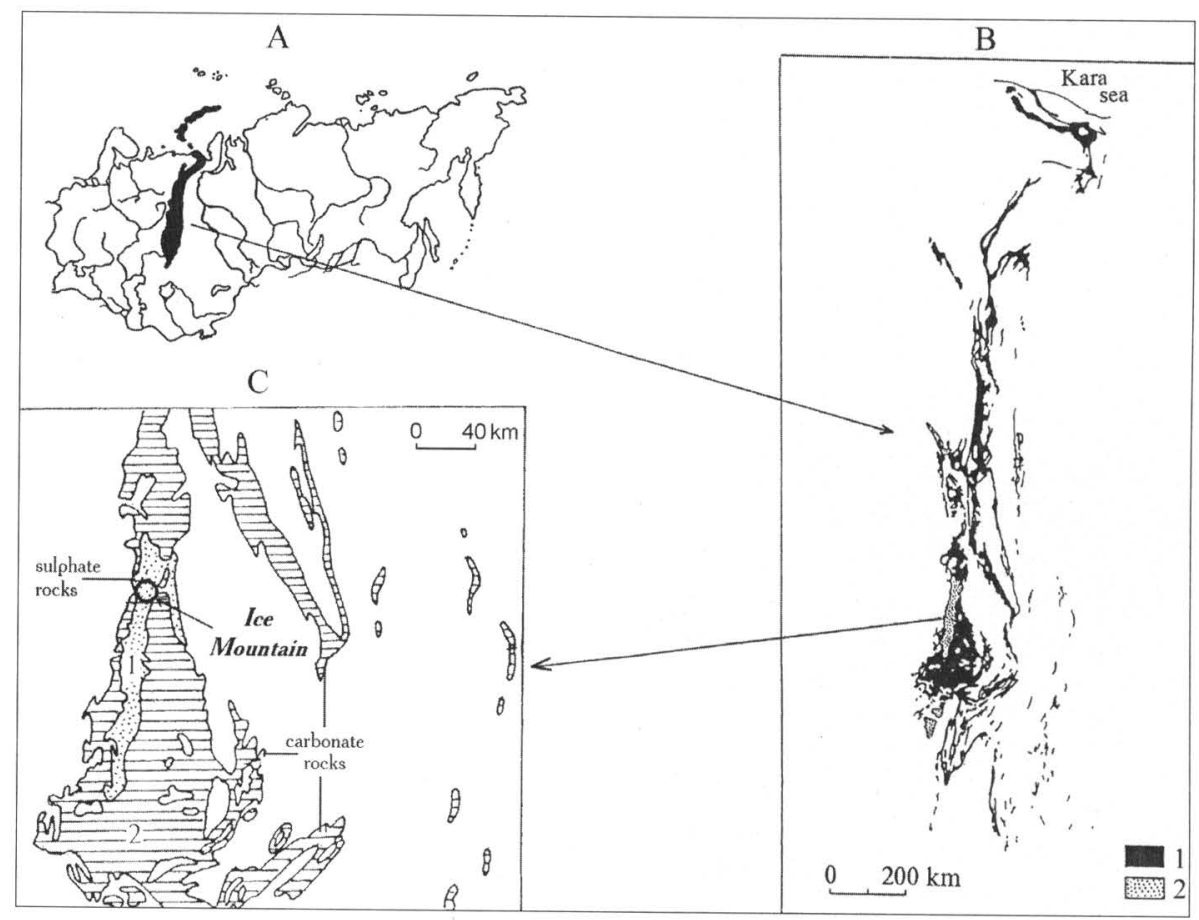

Fig. 1 - Location of the pre-Ural gypsum karst region (A), distribution of carbonate (1) and sulphate (2) rocks in it $(B)$, and the location of the Ice Mountain (C). 


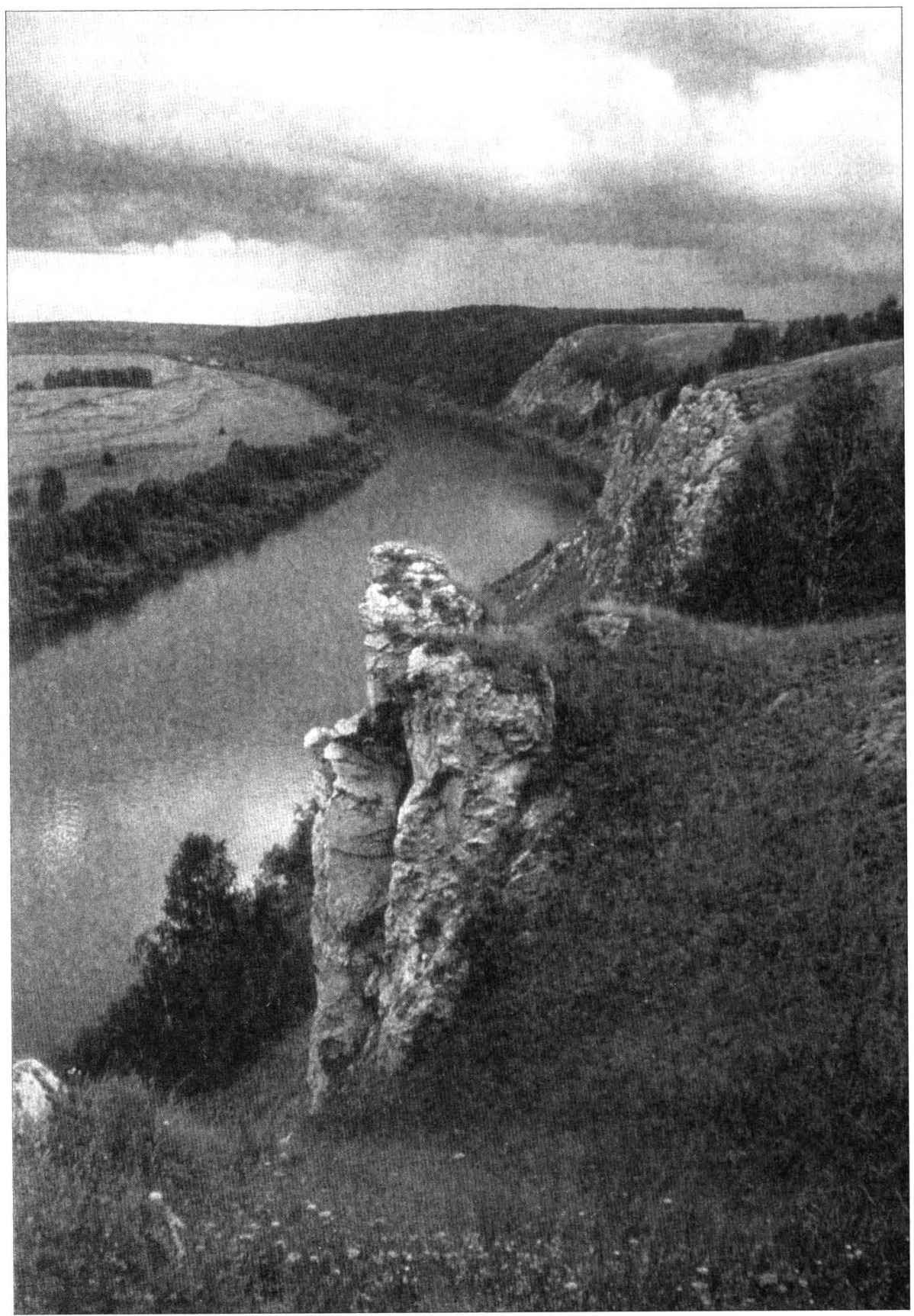

Fig. 2 - Characteristic landscape of the pre-Ural gypsum karst region, with riverside exposures of the sulphate rocks. The Sylva River near the Podkamenskaya village. 
(Fig.3A). The southern flank of the massif, where the entrance is located, is steep and has numerous rocky ledges (Fig.4B). The western and northern flanks are gentle, terraced, and have some protruding residual gypsum hills. The Sylva River is 110 to $120 \mathrm{~m}$ wide and 2 to $3 \mathrm{~m}$ deep near the cave, and it carries 16 to $24 \mathrm{~m}^{3} / \mathrm{s}$ of water during the summer and winter seasons and up to $1300 \mathrm{~m}^{3} / \mathrm{s}$ during spring floods.

The massif comprises the $>70 \mathrm{~m}$-thick sequence of gypsum and anhydrite beds of the Kungursky Stage of the Lower Permian. These rest on the dolomite and limestone beds of the Filippovsky Formation, which is up to $50 \mathrm{~m}$ thick. The formation hosts a

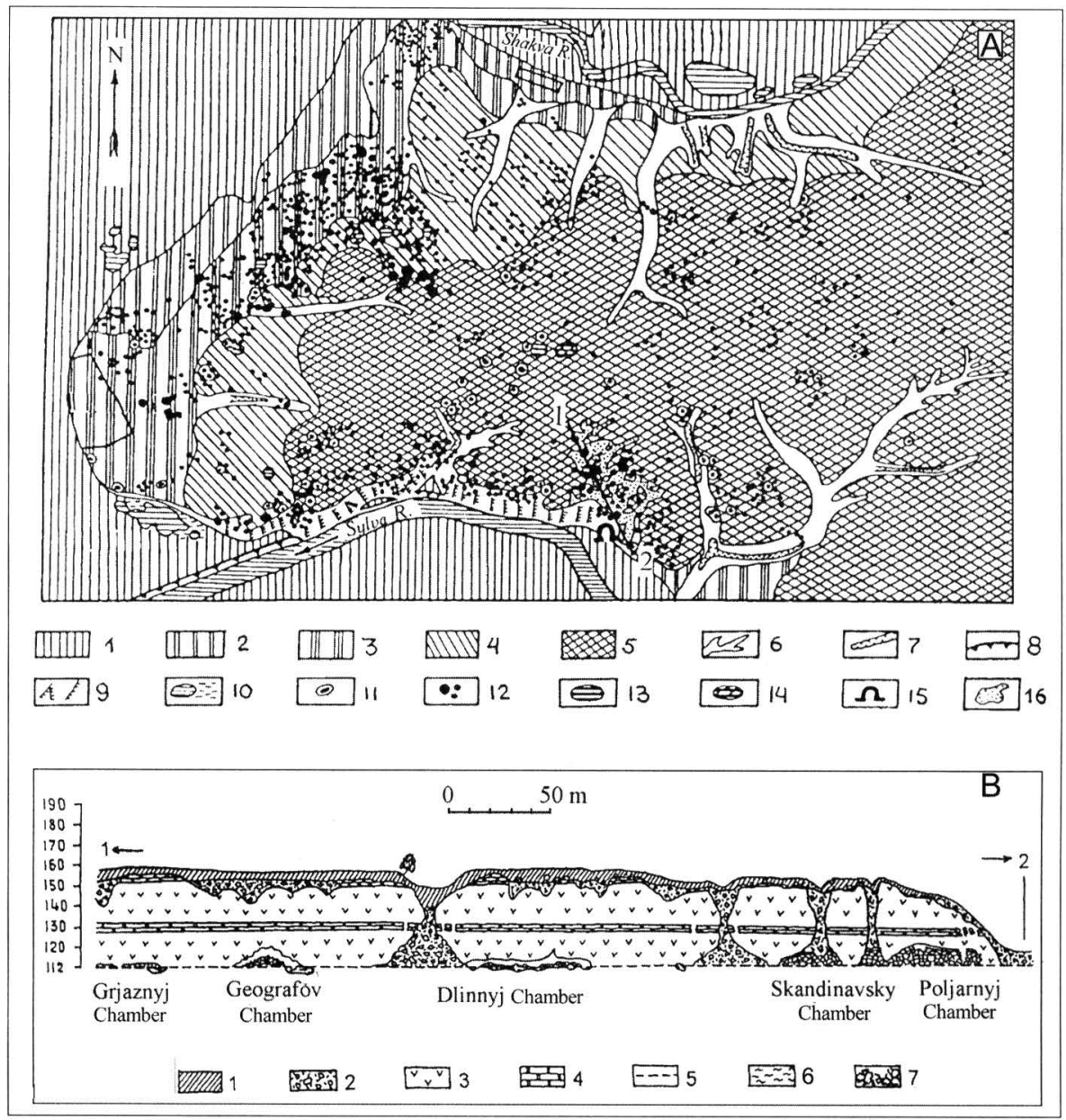

Fig. 3 - Geomorphological map of the Ice Mountain (A) and the geological section (B) showing occurrence of the Kungurskaya Cave.

A: $1-5=$ terraces, $6=$ ravines, $7=$ erosion ditches, $8=$ river trench, $9=$ steep slopes with gypsum ledges, $10=$ modern and former riverbed, $11-$ swallets, $12=$ dolines, $13=$ lakes, 14 = swamped dolines, $15=$ cave entrance, $16=$ cave field .

B: $I=$ loam/soil, $2=$ karst breccia horizon, $3=$ sulphate rocks, $4=$ carbonate rocks, $5=$ water table, $6=$ clay, 8 = breakdown material. 


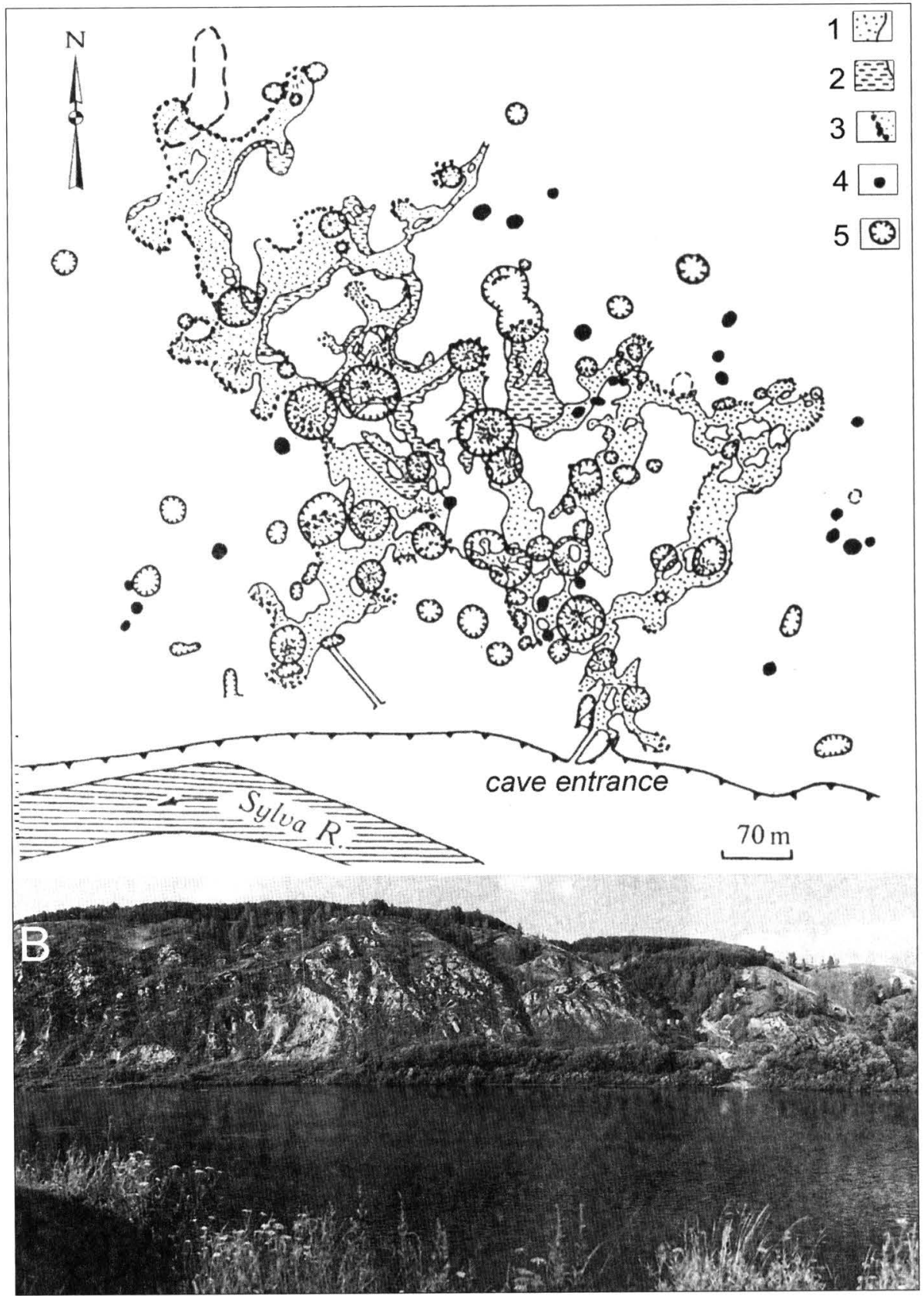

Fig. 4 - Surface karst features above Kungurskaya Cave, superimposed on the cave map (A) and the view $(B)$ of the Ice Mountain from the Sylva River (from the south). $1=$ dry cave passages, $2=$ cave lakes, $3=$ contours by the breakdown material, $4=$ suffosion dolines, $5=$ karst collapse/subsidence dolines. 
good aquifer, with fissure and porous permeability, although at present it represents a relatively less permeable sequence than the overlying sulphates.

The sulphate sequence is known as the Irene Formation and comprises a sequence of gypsum and anhydrite beds alternating with minor layers of limestones and dolomites. Several units are distinguished in the formation, each having its own name. The lowermost sulphate unit (up to $28 \mathrm{~m}$ thick), which rests on the Filippovsky dolomites, is called Ledjanopeshcherskaya (the Ice Cave Unit) and consists of bluegreyish anhydrites and grey gypsum. The dolomite intercalations of 5 to $10 \mathrm{~cm}$ in thickness divide it into three sulphate beds differing in thickness, bedding, structure and fissuring. The cave lies mainly within the Ledjanopeshcherskaya Unit and the different properties of the beds considerably influence the character of breakdown processes.

The Ledjanopeshcherskaya Unit is overlain by the Nevolinsky Unit (4 to $5 \mathrm{~m}$ ), which comprises four beds: grey dolomite $(1 \mathrm{~m})$, oolitic limestone $(1.7-1.9 \mathrm{~m})$, palegrey cavernous limestone $(1.5 \mathrm{~m})$ and dark-grey pelitomorphic dolomite $(0.7 \mathrm{~m})$. Above this is the Shalashninskaya Unit, which comprises a fissured grey gypsum $23 \mathrm{~m}$ in thickness. This unit displays a highly kartsified and irregular rockhead. It is overlain by the Elkinskaya Unit, made up of alternating oolitic limestones, pelitomorphic dolomites and argillites. The uppermost (Demidkovskaya) unit of sulphates (light-grey friable gypsum) is present only in the highest areas of the massif, where it crops out in the flanks of large sinkholes.

The upper part of the geological section of the Ice Mountain massif is substantially destroyed by karstification. Carbonate beds within the sequence, being more resistant to dissolution, experienced uneven settling, disarticulation and mixing, and formed a breccia horizon consisting of dolomitic, limestone, marls, argillite and gypsum clasts. Voids between clasts are infilled by clay. In places clasts are cemented by calcite. Above the breccia horizon, there are clayey-loamy sediments of mixed (alluvial-deluvial) origin, which were formed during extended timescales.

The conditions described, namely the pronounced stratification of the overburden, its lithologic heterogeneity and high degree of fissuring, favour breakdown development.

\subsection{Hydrogeological settings}

The sulphate sequence of the massif is almost entirely in the vadose zone. The groundwater table is located in the lowermost sections of the cave labyrinth, where it is observed in more than 50 cave pools. The aquifer is well connected to the Sylva River due to the high degree of karstification and fissuring. The cave pools are located 120 to $580 \mathrm{~m}$ from the river. In the low regime the river drains the groundwaters through the cave area. During spring floods the high level of water in the river props up the underground waters, causing a rise 3 to $4 \mathrm{~m}$ in the water table and even backflooding. During these periods intense dissolution takes place in the massif, causing concentrated lateral enlargement of the cave.

In Spring time and after rainfalls, a considerable amount of water is retained in the friable loamy sediments and the breccia horizon above the cave, forming a perched aquifer. Its water then leaks slowly down to the cave via fissures. As demonstrated below, this percolation is one of the main factors of the breakdown formation. 


\subsection{Cave morphology and speleogenesis}

The cave is a maze (Fig.4A), developed mainly within gypsums and anhydrites of the Ledjanopeshcherskaya Unit. The total length of the explored cave is of $5.6 \mathrm{~km}$, and its volume is $350,000 \mathrm{~m}^{3}$.

In general the passages are horizontal, but their floors lower gradually from east to west and from the entrance series to depth within the massif. This is due to accumulation in the entrance series (which is the cold part of the cave) of large amounts of clasts generated by frost weathering. In this section both the floors and ceilings of the passages and chambers lie 5 to $6 \mathrm{~m}$ higher than in the far reaches of the cave. Breakout domes are common here, but passages are generally smaller.

Passages in the distant parts of the cave are generally larger, 20 to $40 \mathrm{~m}$ wide and 5 to $10 \mathrm{~m}$ high, with corroded walls. Gravitational processes affect ceilings to varying degrees. The original dissolutional morphology is not preserved at the ceilings. Slab breakdowns occur almost everywhere, and ceilings rise to a height of 10 to $15 \mathrm{~m}$ above the water table. There are many breakout domes with talus or piles of breakdown material below them. In three places large, 20 to $24 \mathrm{~m}$-high breakout domes have formed (the Vyshka-1, Vyshka-2 and Cosmic domes). Because of the breakdown piles below, the actual height of the cave space in these domes remains below $10 \mathrm{~m}$. The ceiling is flat in places, where it reaches the base of the scarcely-fissured anhydrite bed (e.g. in the Smelykh, Velikan, Zapadny and Geologov chambers).

Fragments of large passages are commonly separated by breakdown structures, forming elongated chambers 40 to $100 \mathrm{~m}$ long. They are connected with smaller horizontal conduits, 1 to $20 \mathrm{~m}$ wide and 1 to $6 \mathrm{~m}$ high, which occur along the water table or below it. In contrast to large passages, these conduits have clear dissolutional morphology, almost untouched by breakdown processes.

The cave has a long and complex history of development. During the early stage the cave was developed under confined conditions, by waters rising from the underlying Filippovsky carbonate formation. In the past the nearby river valleys were repeatedly overdeepened relative to the present position, and this imposed vadose conditions within the cave massif. Recent development has occurred mainly at the fluctuating water table, particularly at the expense of aggressive backflooding waters entering the cave from the river during high stands.

\section{The formation of breakdown structures}

The intense breakdown processes in the Ice Mountain massif are evident from both observations in the cave and the wide presence of subsidence sinkholes at the surface (Figs 3A, 4A and 5). Before considering the mechanisms of their formation, it is appropriate to characterise the surface features above the cave.

\subsection{Collapse sinkholes above the cave}

There are more than 3000 hollows of various shapes and sizes on the surface of the massif (Dorofeev, 1979), which makes the density about 300 forms per $\mathrm{km}^{2}$. Among 935 forms mapped in detail on the large-scale plan, cone-shaped dolines are predominant $(57 \%)$. Bowl-shaped dolines comprise $26.8 \%$ and saucer-like dolines $9.5 \%$. The rest are trenches and pits formed along unloading fissures near the plateau edges $(6.2 \%)$, or large depressions $(0.5 \%)$ and other forms. 


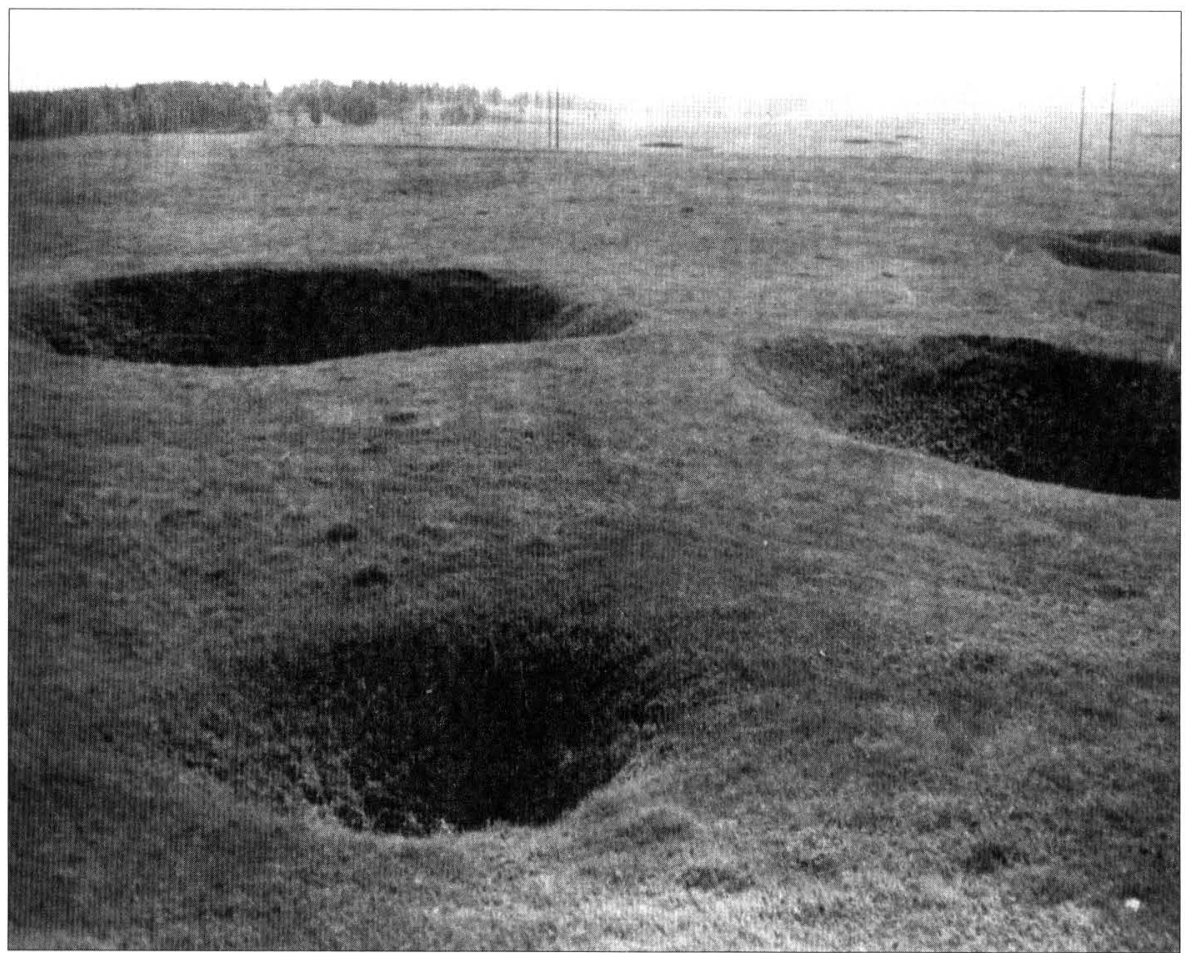

Fig. 5 - Typical dolines above Kungurskaya Cave (photo by E.Dorofeev).

Of the total number of mapped hollows, $640(68.5 \%)$ are located on the surface of the Ice Mountain massif, $197(21.1 \%)$ lie on its slopes, and $98(10.5 \%)$ are in the thalwegs of ravines. According to the density and character of hollows four zones are distinguished (Dorofeev, 1968, 1970): steep slopes $\left(<200 \mathrm{forms} / \mathrm{km}^{2}\right)$, edges $(500$ $\left.1000 \mathrm{forms} / \mathrm{km}^{2}\right)$, gentle (upper) slopes (200-300 forms $\left./ \mathrm{km}^{2}\right)$ and terrace/watershed $\left(<200 \mathrm{forms} / \mathrm{km}^{2}\right)$. Concentration of karstic hollows in the edge zones is linked to the development of unloading fissures, removal of cover sediments and exposure of the sulphate rockhead. Small and randomly distributed forms predominate in this zone. In the gentle slope zone (200 to $400 \mathrm{~m}$ away from the edges) karst hollows are relatively large. For instance, dolines 10 to $30 \mathrm{~m}$ wide and 4 to $10 \mathrm{~m}$ deep predominate on the surface above the cave, the largest reaching $60 \mathrm{~m}$ in diameter and $13 \mathrm{~m}$ in depth. Most of the dolines are separate, and randomly distributed. An increase of doline size towards the watersheds is explained by the increasing thickness of friable sediments, in which the dolines develop.

On the plateau, small- and medium-sized dolines predominate (Fig.5; see also Fig.13), commonly with signs of periodic activation. These dolines are clustered. Old saucer-shaped waterlogged dolines are widespread, but fresh collapses are also common. Between 1943 and 1986134 new collapses were recorded within the Ice Mountain (Dorofeev, 1979; Dorofeev and Anrejchuk, 1990). Most of these were less than $4 \mathrm{~m}$ in diameter and $2 \mathrm{~m}$ in depth (Table 1). Fresh collapses commonly occurred at the bottom or on the slopes of the older dolines $(54 \%)$ or less than $20 \mathrm{~m}$ from them 
Table 1. Distribution of 134 collapses formed between 1943 and 1986, in terms of diameter and depth (after Dorofeev, 1979)

\begin{tabular}{|c|c|c|c|}
\hline Diameter, $\mathrm{m}$ & $\%$ & Depth, $\mathrm{m}$ & $\%$ \\
\hline$<1$ & 34 & $<1$ & 68 \\
\hline $1-2$ & 21 & $1-2$ & 18 \\
\hline $2-4$ & 27 & $2-4$ & 12 \\
\hline $4-6$ & 15 & $>4$ & 2 \\
\hline$>6$ & 3 & & \\
\hline
\end{tabular}

$(25 \%)$. This is considered to be an important diagnostic indication of a particular breakdown mechanism.

Thorough underground observations have revealed that collapse/subsidence features above the cave have different origins, which explain peculiar features of their distribution on the Ice Mountain massif. Most of the breakdown structures develop according to a vertical dissolution pipe mechanism (infiltrational/gravitational) or, less commonly, by failure of the ceilings of large cavities (gravitational mechanism). Some features originate due to the suffosional mechanism. These three types are considered below, starting with the "classic" gravitational mechanism.

\subsection{Breakdown development by the gravitational mechanism}

Whereas it is appreciated that all types of karst breakdown involve the action of gravity forces, the term "gravitational mechanism" is used here to denote "purely" mechanical failure of cave roofs under load, without significant involvement of other processes such as percolation, erosion, suffosion, liquefaction, etc.

In Kungurskaya Cave 64 rock failure events were recorded during the period from 1963 to 1986 (Dorofeev, 1987). The actual number of failures was probably far greater, as only the largest events in easily accessible areas of the cave were documented. The prevailing type of failure is slab breakdown (sensu White and White, 2000), although less frequent breakdowns of blocks measuring 3 to $5 \mathrm{~m}$ also occur. Continuous failures of passage ceilings result in clast accumulation at the bottom and upward migration of voids. Many parts of the cave are completely filled with breakdown clasts. In some places large breakout domes form, with dome-like or conic piles of clasts below, e.g. in the Velikan, Meteorny and Geografov chambers (Fig.6).

The most intense contemporary breakdowns are found within the entrance series, where seasonal and daily ranges of temperature are substantial and repeatedly pass through zero. Ice wedging in cracks and fissures ruptures the rock during cold days, with noise that resembles muffled gunshots. In the warmer part of the cave (the main part, which exhibits a constant positive temperature) failures are most frequent in those chambers with large ceiling spans. These include the Velikan Chamber $(40 \mathrm{~m}$ span and 7 failure events during the above-mentioned period) and the Vyshka Chamber (30m span and 11 failure events). Stratification and the degree of fissuring of particular rock packages also influence the intensity of breakdowns. A layer of the lumpy gypsum in the upper part of the Ledjanopeshcherskaya Unit is most suscepti- 

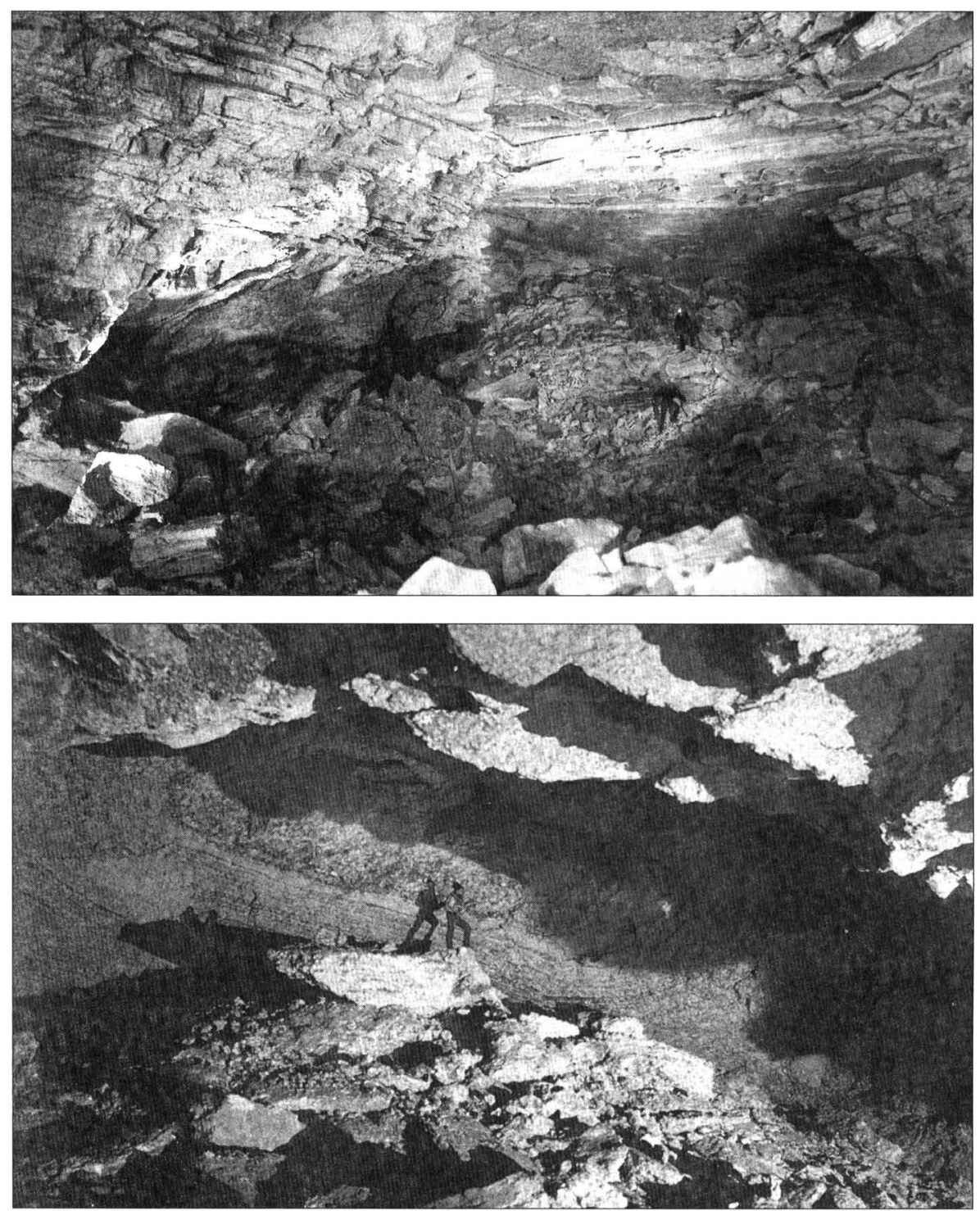

Fig. 6 - Breakout domes and breakdown taluses originated by slab and block breakdown in Kungurskaya Cave. $A=$ Velican Chamber, $B=$ Casteret Chamber.

ble to failure. Much less commonly breakdowns affect a bed of massive anhydrite within the same unit, which fails by collapse of large blocks.

Continuous elastic sagging of beds across large passage spans is common throughout the cave (Fig.7). It normally precedes and accompanies the failure (Fig.8).

Almost the full thickness of the rocks above the cave is characterised by undulating beds, representing a vivid example of "karst tectonics". The amplitude of bend- 


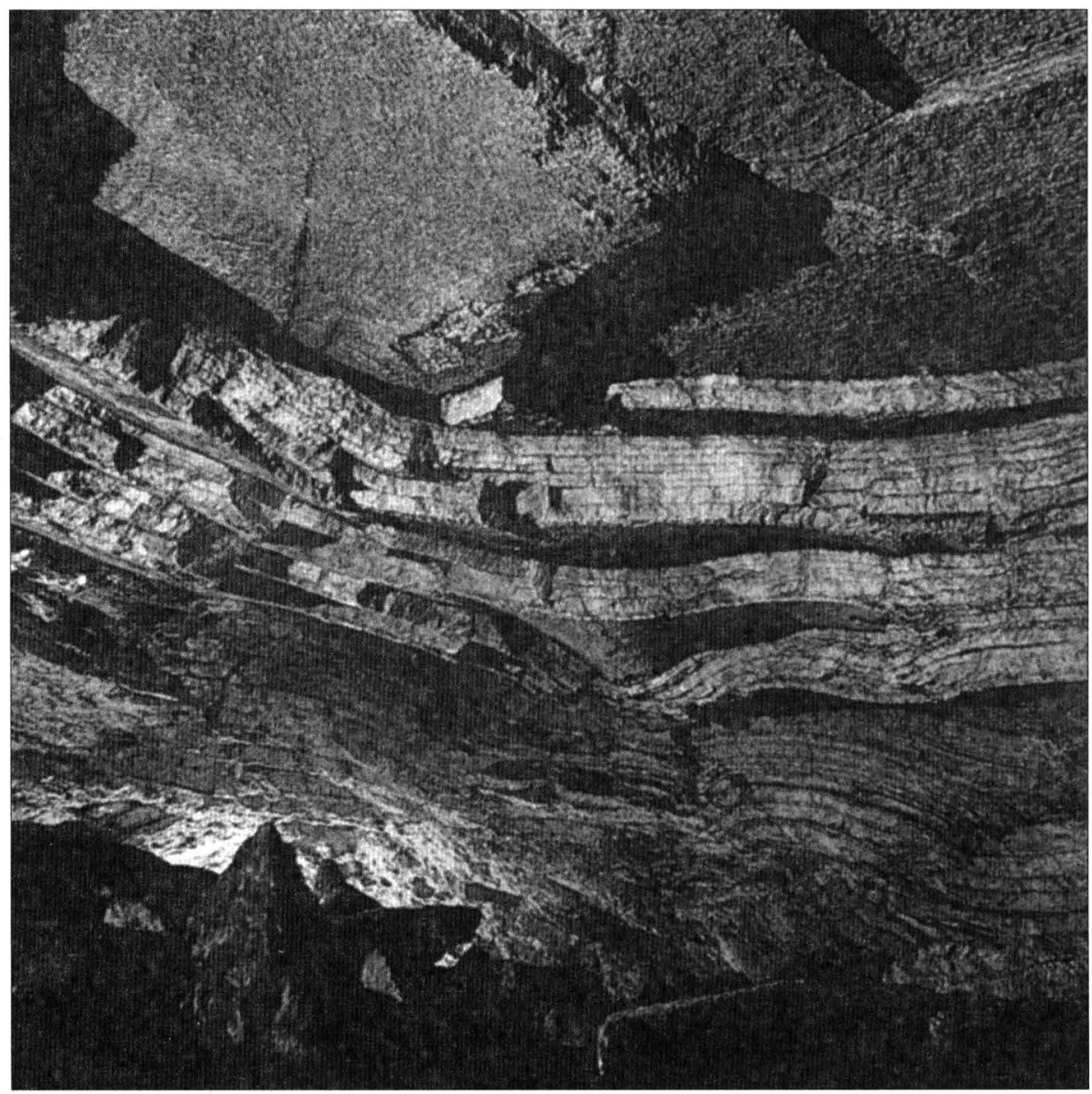

Fig. 7 - Elastic sagging of gypsum beds in the ceiling of Ruiny Chamber.

ing reaches 3 to $5 \mathrm{~m}$. It is noteworthy that the observed dip of beds at the ceiling is not always directed towards the centre of the span, but commonly towards the walls. This is due to polycyclic karstification and the presence of various generations of cavities of different ages, including paleokarstic cavities filled with karst breccia.

It appears that ceilings have not achieved a stable morphology, even in well developed large breakout domes, and the domes continue to grow. Despite this and the fact that gravitational breakdown mechanism is the most common through the cave area, it does not result in collapses at the surface. Gradual upward stoping of cavities due to breakdown and consequent accumulation of fallen clasts bring about reduction of stoping voids in volume and self-arrest of the breakdown process (Fig.9). This is because the bulk volume of the accumulated breakdown material is larger than the volume of the solid source rock, an effect previously noted by Šušteršič (1973, 1974). Growth of a breakdown pile surpasses upward growth of the void ceiling, and the rate of the advancing growth of the pile depends on the coefficient of rock loos- 


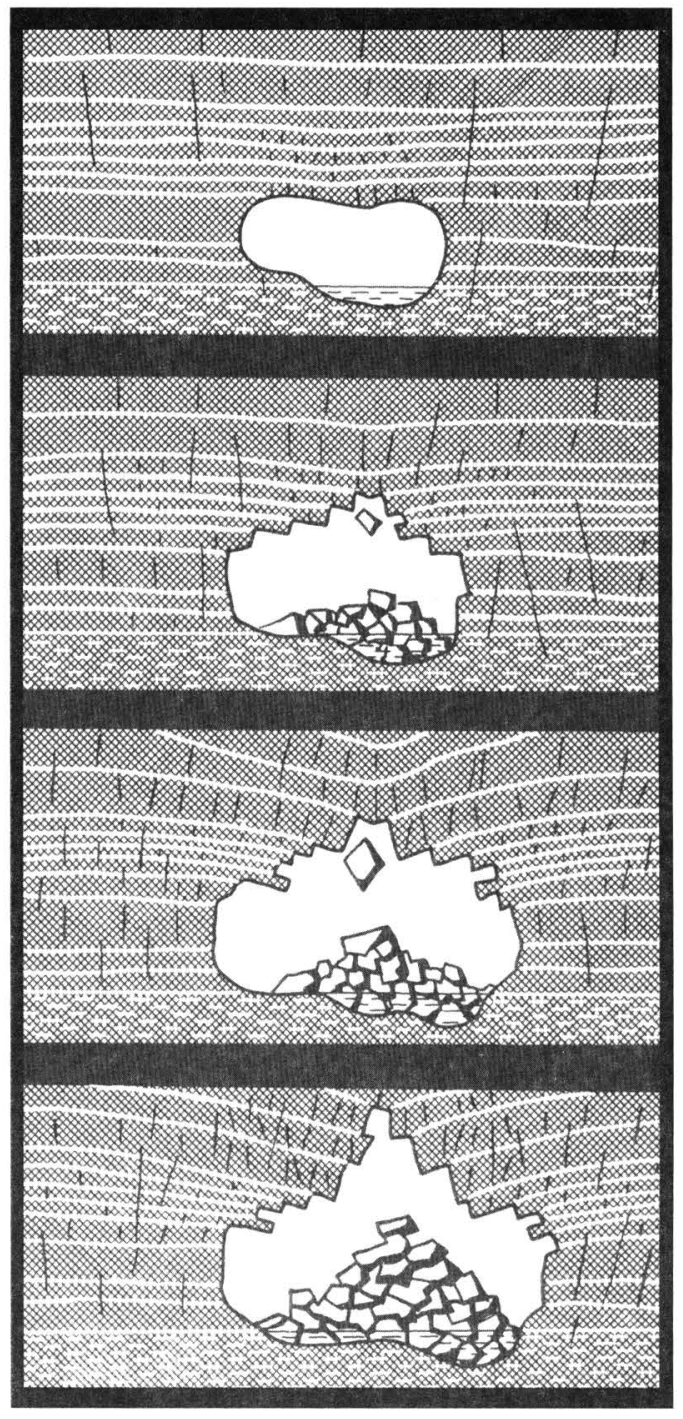

Fig. 8 - Diagram showing conjugate sagging and slab fall-in processes. wide breccia zone stretches northeast for $100 \mathrm{~m}$. The large size of the ancient cavity is evidenced by the presence of 1 to $2 \mathrm{~m}$-wide blocks of Nevolinskaya Unit dolomite, encased in the breccia, some $20 \mathrm{~m}$ below the source bed. The lowermost parts of the breccia zones lie below the modern floor of the passages in places. This indicates a possible Pliocene age for the self-sealing of such cavities, which could be related to the period 3 million years ago when the Sylva river and its tributaries were entrenched below the modern position.

ening. The latter is the ratio of the volume of the bulk mass of fallen clasts to the volume of the solid source rock. This coefficient $\left(K_{\text {loos }}\right)$ may vary from 1 to $>2$, increasing from friable sandyclayey materials to solid rocks, and from crumble breakdown to block breakdown. Provided the overburden is sufficiently thick, the breakdown pile overtakes the breakout vault at a certain height. This relieves the stress and arrests the process of void propagation. The breakdown structure will not reach the surface in this case and no collapse will appear.

The described phenomenon of self-regulation of the breakdown process, vividly displayed in Kungurskaya Cave, explains the absence of large collapses above the cave, despite the large spans of cave passages. It also accounts for the formation of karst breccia. Elastic sagging of the sulphate rock continues for a some time after the breakdown pile has reached the ceiling, causing some loading of the pile and compaction of the breakdown material. With time the latter transforms into brecciated rock. Brecciated zones and bodies of breccia ("fillings" of former cavities of various ages) are observed widely in the cave, intersecting with the present passages in different ways. For instance, between Ruin Chamber and Meteorny Chamber a $60 \mathrm{~m}$ - 


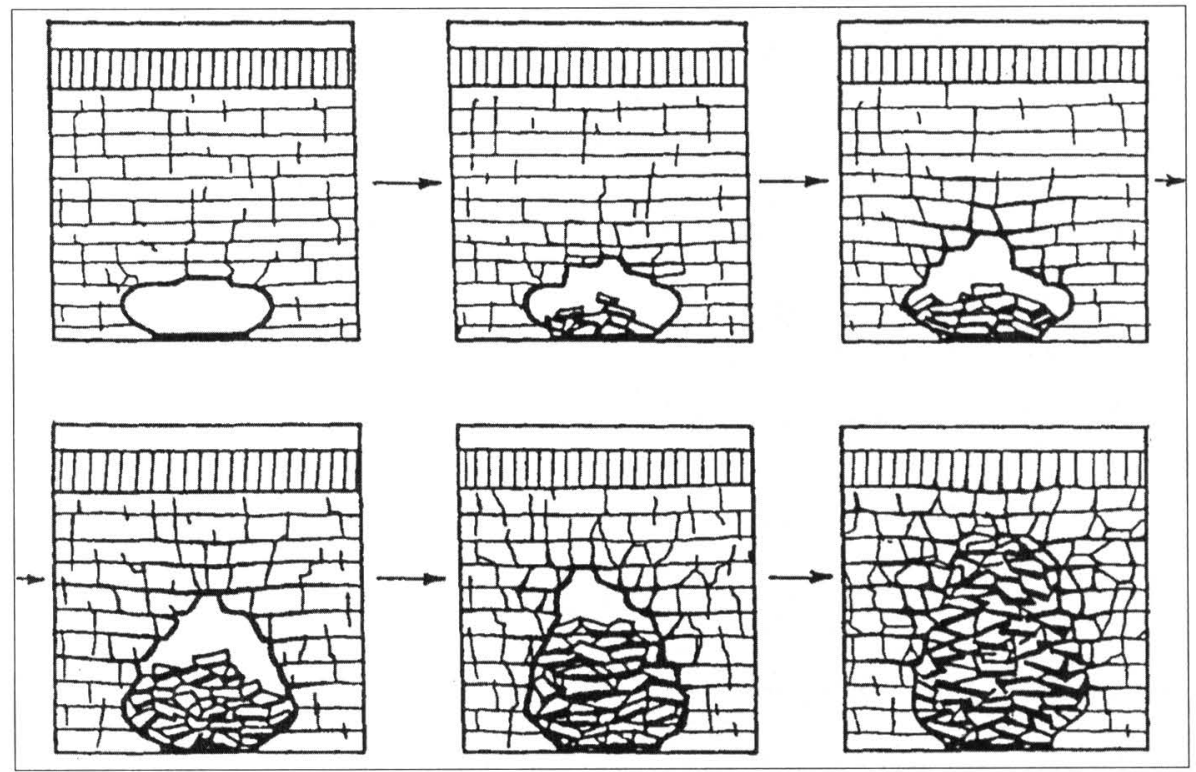

Fig. 9 - Ceasing of gravitational breakdowns in the process of upward stoping.

Walls with exposed karst breccia can easily be recognized by chaotic interrupted bedding and encased broken pieces and blocks of dolomite (Fig.10A), and by a spongework pattern of small dissolution voids (Fig. 10B).

\subsection{Breakdown development by the vertical solution pipe mechanism}

Vertical solution pipes (VSP) are rounded channels that perforate the sulphate thickness vertically above the cave. They are also known as "organ pipes" and "comins". VSP are common in many entrenched gypsum karsts such as the PinegoSeverodvinsky region in Russia and the Western Ukraine. They form by aggressive waters leaking through the vadose zone from perched aquifers above (Fig.11A), become superimposed upon horizontal cavities developed earlier and play an important role in initiating and guiding the breakdown processes (Klimchouk and Rogozhnikov, 1984; Andrejchuk, Dorofejev and Lukin, 1997; see also paper by Klimchouk and Andrejchuk in this volume).

In the Kungurskaya Cave 146 VSP have been mapped (Fig.11B) with diameters ranging from 0.2 to $10 \mathrm{~m}$. They reach a height of 10 -to $20 \mathrm{~m}$. Most of the pipes are wider at the mouth, although cylindrical pipes are also common. The walls are entrenched by corrosion flutes. VSP form along paths through which water leaks from the perched aquifer. Almost all percolation in the vadose zone is concentrated in VSP, the blocks between them being completely waterless. Dripping of water commonly occurs in pipes superimposed on horizontal passages. In some pipes dripping intensity increases considerably during snowmelt at the surface, whereas in others it oscillates with no pronounced correlation to seasons or weather. These variations reflect differences in capacity and retention characteristics in different parts of the perched aquifer, and in configuration of leakage paths. Total dissolved solids in drip- 

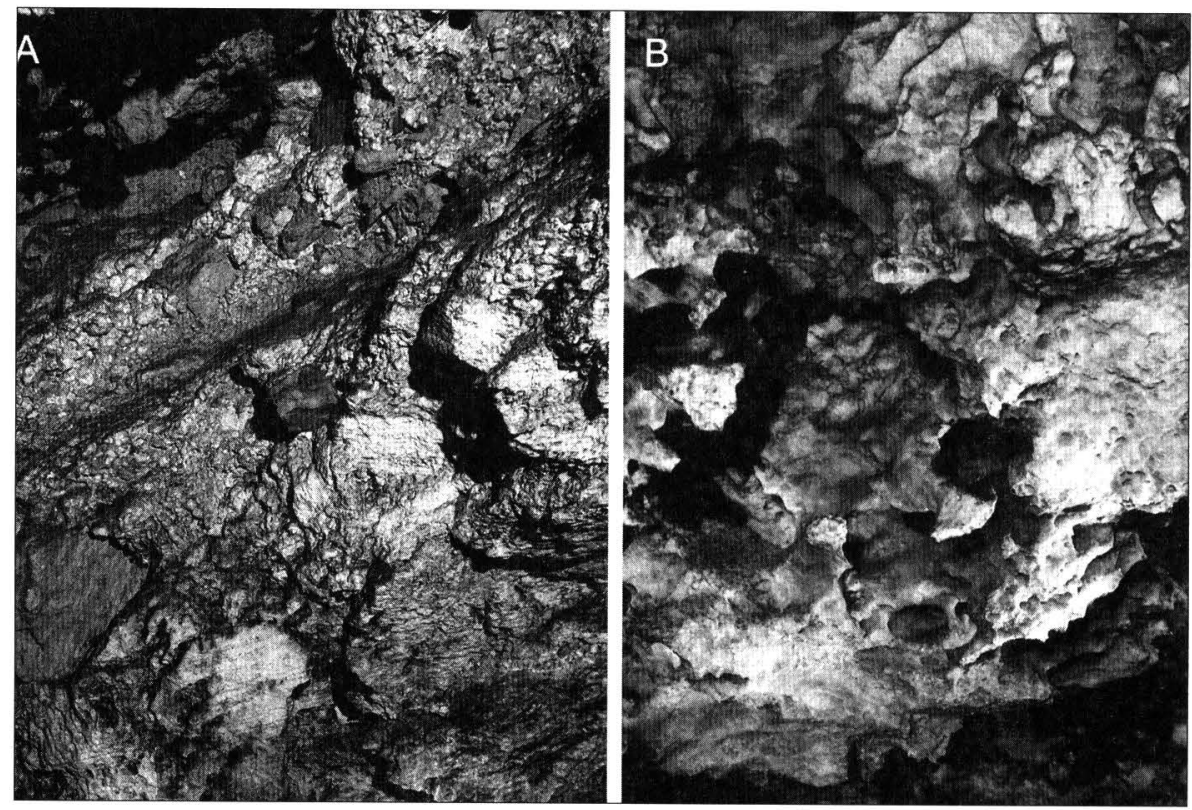

Fig. 10 - Cave walls composed of karst breccia.

ping water varies between pipes and intensity regimes from 0.6 to $2.0 \mathrm{~g} / \mathrm{L}$, depending of the length (time) of immediate contact of the water with the sulphate rock. A few dripping spots in the cave, associated with cracks in ceilings and yielding supersaturated water, probably indicate recent VSP that started to develop above but have not yet reached the cave.

Carbonate beds within the otherwise sulphate sequence divide the pipes into 2 or 3 sections in the vertical profile. Being fissured, these beds let water percolate downwards into the next pipe section but retain loose material, thus preventing the lower sections from being filled (Fig. 12A). Different sections of a pipe can be aligned along the same vertical fissure and match each other in plan view, or they can be shifted laterally up to few metres after crossing a carbonate bed according to fissure guidance in respective sulphate beds.

The growth in pipe diameter and attendant filtration cause collapse and subsidence development at the surface (Fig.11A). The overwhelming majority of dolines above the Kungurskaya Cave were formed by breakdown processes related to the development of vertical solution pipes. This is confirmed by the coincidence of almost all dolines in the cave field with pipes and related breakdown piles mapped in the cave (compare Fig.4A and Fig.11B), a fact noted by Dorofeev (1968). A mismatch of a few metres between the centres of some dolines and the pipes mapped in the cave is explained by the lateral shift of different vertical segments in some pipes where they cross the carbonate beds. Some pipes, however, do not have dolines above them. These have not yet reached the uppermost unit. The position of the top of the pipe in the vertical section can be inferred from the composition of the breakdown pile below the pipe.

The mechanisms of breakdown development along VSP may vary depending on 

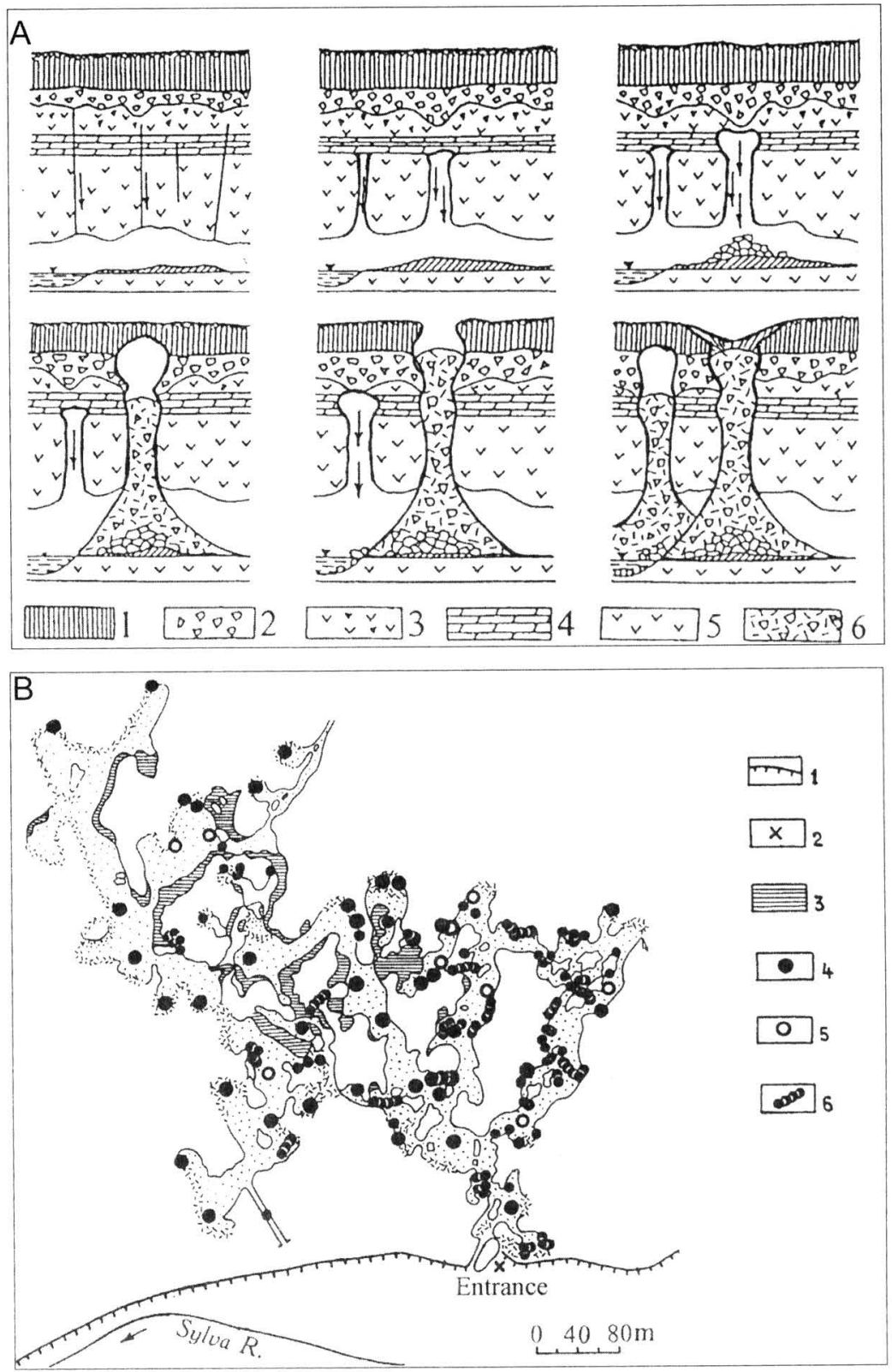

Fig. 11 - Doline formation due to the gravitational/filtration mechanism, after vertical solution pipes $(A)$, and distribution of the biggest pipes in Kungurskaya Cave.

A: $1=$ loam, 2 = karst breccia horizon, $3=$ gypsum, $4=$ limestoneldolomite, $5=$ gypsum/anhydrite, $6=$ breakdown material.

$B: 1=$ gypsum scarp, 2 = cave entrance, $3=$ cave lakes, $4=$ infilled VSP, $5=$ open VSP, $6=$ chain of pipes 

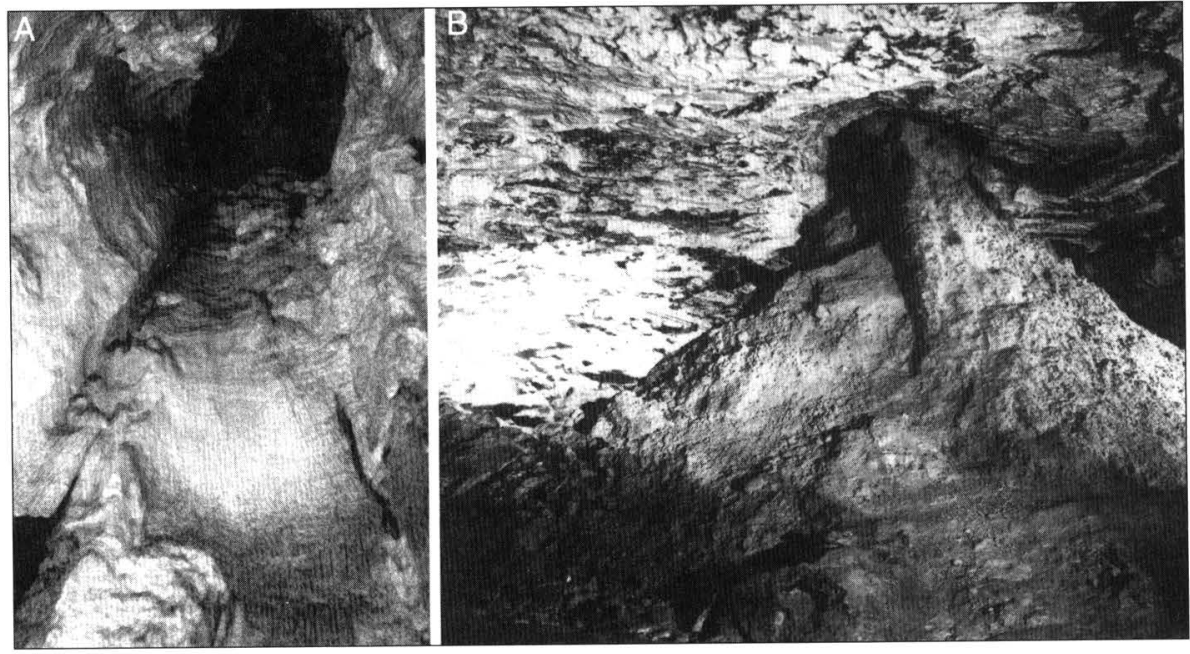

Fig. 12 - Open vertical solution pipe (A; view from below) and breakdown pile below a pipe $(B)$ in the Efirny Chamber. Photo by E.Dorofeev.)

which particular horizon (perched aquifer) gave rise to the pipe. If the pipe is fed from the carbonate beds of the Nevolinsky Unit, it develops only in the underlying sulphates. Growth of the pipe diameter will cause collapse of the bridging Nevolinsky Unit at some stage and further growth by upward stoping through the overburden. The surface feature will most likely evolve as a collapse.

More commonly pipes evolve due to leakage from the uppermost horizons of breccia and loams, supporting a perched aquifer. In such cases, small conic sinkholes form at the surface due to suffosion of the friable cover, starting during early stages of pipe growth. Formation of initial suffosion dolines accelerates the development of pipes below, due to piracy of surface runoff. Subsequent increase of the pipe diameter in the sulphate strata causes internal collapse of the separating carbonate beds and eventually the final collapse of the bridging breccia and loams. Where the thickness of the friable cover is small, pipes may open to the surface as shafts. If the thickness is considerable, the pipe can be filled completely by breakdown material after collapsing, and collapse dolines appear at the surface.

The breakdown mechanisms after vertical solution pipes, inferred from observations in the Kungurskaya Cave, can be extrapolated across the entire region. This is supported by the wide presence of VSP (they can be observed in valley outcrops and quarries as well as in caves) and also by the characteristics of fresh collapses. As the main gauging factor for the size of fresh collapses is the diameter of guiding pipes below, their diameters should correspond to the diameters of pipes. According to Lukin and Ezhov (1975), the initial diameters of the collapses that occurred in the Kungur region during many years were 0.5 to $5.0 \mathrm{~m}$. In the Kungurskaya Cave diameters of $83 \%$ of pipes fall in this range.

Further evolution of dolines evolved through the VSP mechanism is guided by the processes in the pipes. Pipes continue transporting breakdown and wash-out material underground, and the process is facilitated by continuing filtration through them. In addition to draining the perched aquifer, pipes now receive an increasing amount 
of surface run-off. The upper part of the pipes enlarges more quickly and generally the pipes assume a funnel-shape, with more complex relief in detail. Breakdown filling settles in the pipe due to dissolution and erosion in the breakdown column, and so both the depth and diameter of the doline increase. Periodically, fresh concentric cracks and small collapses may appear in the floor of the doline. This continues until the passage below is completely filled. Erosion at the base of the breakdown column may further facilitate doline growth, but eventually the breakdown column is sufficiently compacted to suppress active filtration, and doline growth ceases. Any further modification is mainly directed towards the softening of slopes and decrease of depth, although re-activation of settlement in the pipe may occur.

So, the size of the passage, though not influencing the initial diameter of collapse, does exert an influence, through its receptacle capacity, upon the size of a mature doline. This is why dimensions of mature dolines are commonly equal to the widths of cave passages below them, or are slightly less (Table 2). Only two dolines (above the Efirny and Geografov chambers, lines 9 and 17 in Table 2) have diameters substantially less than the widths of cavities below them, which indicates their immaturity and continuing growth. This is also evidenced by the steep slopes of these dolines and the apparent activity of the related breakdown piles in the cave. The correspondence of doline dimensions and their related receptacle cavities, which can be expressed by their ratio (the final column in Table 2), indicates the morphological maturity of dolines. If the $D / B$ ratio is higher than 1 , sedimentation processes and morphological smoothing predominate. Most dolines within the cave field have stopped growing.

The ratio of doline depth to diameter (H/D) also indicates the evolutionary state of the feature. This ratio is 0.25 to 0.30 for the most of the dolines above the cave, whereas it is 0.38 and 0.52 for the two dolines mentioned above that are still growing.

The volume of dolines always exceeds the volume of the breakdown piles below the pipes, despite of loosening of the breakdown material (Table 3). Volume discrepancy is explained by that part of the breakdown material that fills the pipe. The difference characterizes the volume of the pipe.

The above characteristics of breakdown formation related to vertical solution pipes lead to several important conclusions about related surface forms:

- Initial dimensions of surface collapses (at the time of the event) are determined by the diameters of pipes and the heights of the underlying cavities.

- Dimensions and shape of dolines observed at the surface reflect the evolutionary state of the features.

- Mature (stable) dolines imply cessation of material transport in the pipe, and their dimensions point to the widths of the receptacle cavities.

- Large doline size is not necessarily determined by the large size of the initial collapse and, conversely, the small size of a collapse does not reflect the size of the subsequent mature doline.

\subsection{Dolines formed by suffosion}

Some dolines at the surface of the Ice Mountain were formed without any relation to cavities of the Kungurskaya Cave type, due to suffosion washout of loose 
Table 2. The correspondence of dimensions of conjugate dolines and cave passages within the field of influence of Kungurskaya Cave (modified after Dorofeev, 1970)

\begin{tabular}{|c|l|c|c|c|c|c|}
\hline № & $\begin{array}{c}\text { Chamber } \\
\text { (passage) }\end{array}$ & $\begin{array}{c}\text { Width of } \\
\text { cavity below } \\
\text { pipe, } \mathrm{m} \\
\mathrm{B}\end{array}$ & $\begin{array}{c}\text { Diameter of } \\
\text { doline, } \mathrm{m} \\
\mathrm{D}\end{array}$ & $\begin{array}{c}\text { Depth of } \\
\text { doline, } \mathrm{m} \\
\mathrm{H}\end{array}$ & $\begin{array}{c}\text { Doline depth to } \\
\text { doline diameter } \\
\text { ratio } \\
\text { H/D }\end{array}$ & $\begin{array}{c}\text { Doline diameter } \\
\text { to cave width } \\
\text { ratio } \\
\text { D/B }\end{array}$ \\
\hline 1 & Poljarny & 30 & 22 & slope & - & 0,73 \\
\hline 2 & Skandinavsky & 16 & 15 & 4,0 & 0,27 & 0,94 \\
\hline 3 & Sklep-Zapadny & 45 & 42 & 14,0 & 0,33 & 0,93 \\
\hline 4 & Krestovy & 35 & 30 & 3,8 & 0,13 & 0,86 \\
\hline 5 & Smelykh & 25 & 32 & 9,8 & 0,30 & 1,28 \\
\hline 6 & Geologov & 19 & 20 & 5,0 & 0,25 & 1,05 \\
\hline 7 & Grozny & 30 & 30 & 9,5 & 0,32 & 1,00 \\
\hline 8 & Kolizej & 33 & 30 & 9,0 & 0,30 & 0,90 \\
\hline 9 & Efirny & 30 & 12 & 6,3 & 0,52 & 0,40 \\
\hline 10 & Mokraja Kochka & 20 & 15 & 5,0 & 0,33 & 0,75 \\
\hline 11 & Atlantida & 13 & 30 & 7,5 & 0,25 & 2,03 \\
\hline 12 & Khlebnikovykh & 40 & 39 & 10,9 & 0,28 & 0,98 \\
\hline 13 & Zaozerny & 37 & 38 & 13,2 & 0,35 & 1,03 \\
\hline 14 & Dlinny & 27 & 20 & 5,0 & 0,25 & 0,74 \\
\hline 15 & Velikan & 31 & 37 & 6,9 & 0,23 & 1,19 \\
\hline 16 & Kosmichesky & 60 & 55 & 12,0 & 0,25 & 0,92 \\
\hline 17 & Geografov & 40 & 20 & 7,5 & 0,38 & 0,50 \\
\hline
\end{tabular}

Table 3. Relationship between doline volume and the volume of breakdown piles in Kungurskaya Cave (after Dorofeev, 1970)

\begin{tabular}{|c|l|c|c|c|}
\hline № & Chamber (passage) & $\begin{array}{c}\text { Volume of breakdown } \\
\text { piles in the cave, } \mathrm{m}^{3} \\
\mathrm{~V}_{\mathrm{p}}\end{array}$ & $\begin{array}{c}\text { Volume of doline, } \mathrm{m}^{3} \\
\mathrm{~V}_{\mathrm{d}}\end{array}$ & $\begin{array}{c}\text { Volume of material } \\
\text { in the pipe, } \mathrm{M}^{3} \\
\mathrm{~V}_{\mathrm{p}}-\mathrm{V}_{\mathrm{d}}\end{array}$ \\
\hline 1 & Efirny & 500 & 670 & 170 \\
\hline 2 & Velikan & 3520 & 4210 & 690 \\
\hline 3 & Smelykh & 3020 & 4880 & 1860 \\
\hline 4 & Sklep-Zapadny & 10780 & 13480 & 2700 \\
\hline
\end{tabular}

Quaternary sediments into small cavities and large fissures in the breccia horizon that immediately underlies the cover. The main diagnostic feature of this type of dolines is their small size (diameter 0.5 to $2 \mathrm{~m}$ and depth 0.5 to $1.0 \mathrm{~m}$; Fig. 13 ), which is determined by the small sizes of receptacle cavities and fissures between boulders in the breccia horizon. They commonly appear as gradual subsidences, although small collapses also occur. With time, such dolines may gain larger diameters (up to 3 to $5 \mathrm{~m}$ ), and their discrimination from dolines formed by the VSP mechanism becomes problematical. The morphometric criteria are ambiguous, and distinguishing this type would be difficult without precise comparison of surface and underground features 


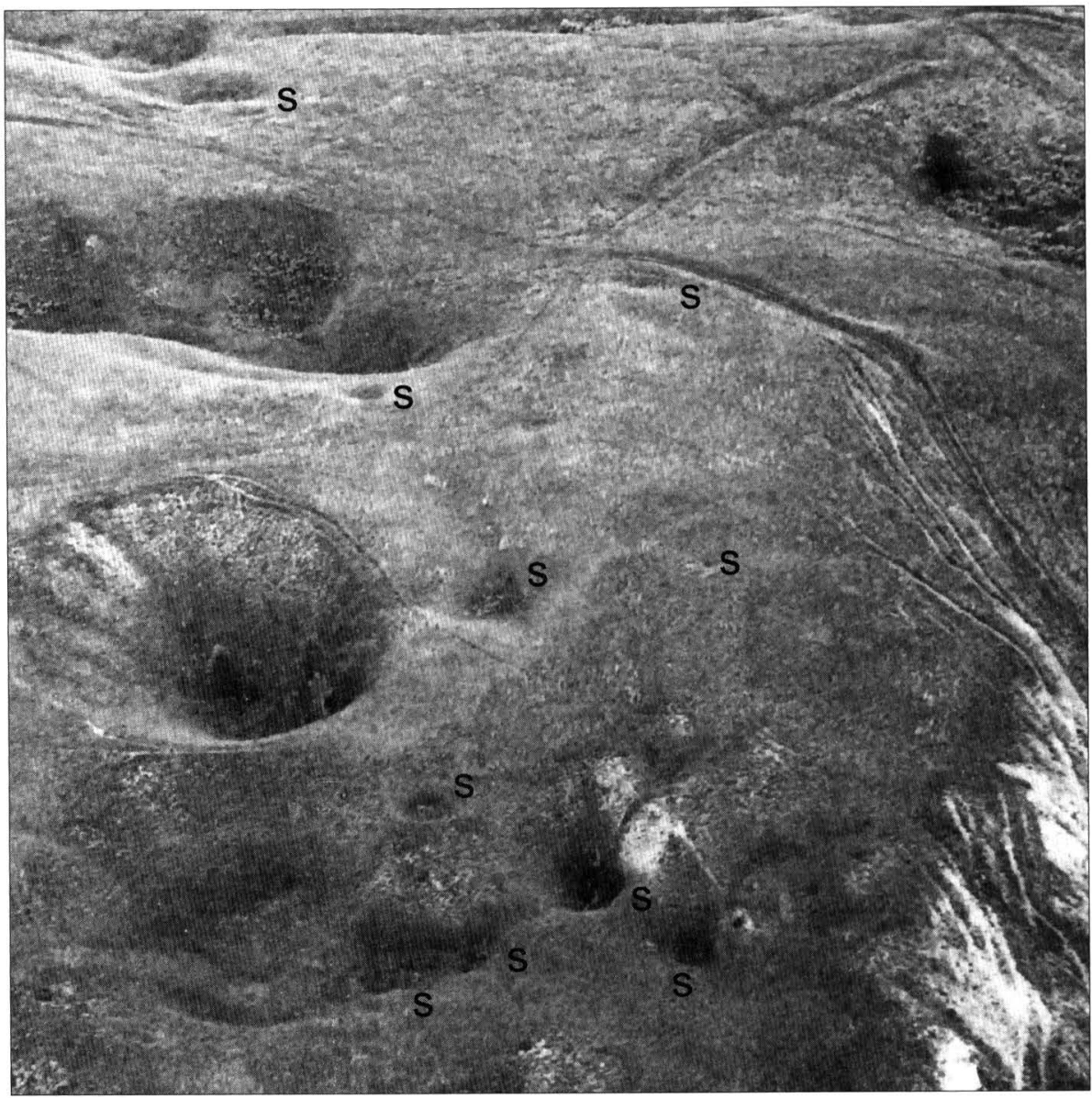

Fig. 13 - Typical dolines formed due to suffosion into the karst breccia horizon (marked by "s") on the surface of the Ice Mountain. Bigger dolines are related to the vertical solution pipes.

within the cave field. For instance, six small dolines are located immediately above cave passages (see Fig.4A) but there are no percolating fissures, pipes and breakdown piles in the related underground locations.

\section{Subsidence hazard assessment}

Detailed mapping of breakdown structures in caves facilitates precise hazard assessment with respect to cave-related collapse/subsidence features (see also paper by Klimchouk and Andrejchuk in this volume). However, such an assessment remains site-specific, accomplishable only for the areas of cave fields. Nevertheless, an understanding of the mechanisms of breakdown formation, gained from speleological observations, allows development of more adequate approaches to subsidence hazard assessment in areas holding similar geological, hydrogeological and speleogenetic characteristics. 
The sulphate karst of the fore-Ural is generally characterized by:

- incomplete opening of the soluble rocks by river valleys;

- presence of a 10 to $80 \mathrm{~m}$-thick vadose zone in sulphate massifs;

- dense fissuring and stratification of sulphate rocks;

- presence of a 5 to 30m-thick karst breccia horizon and loose Quaternary sediment cover at the tops of massifs.

The situation on the Ice Mountain is representative of the sulphate karst of the region as a whole; hence the breakdown formation mechanisms revealed by this study can reasonably be extrapolated across the entire region.

This study suggests that collapse and subsidence dolines in the Ice Mountain evolve through several distinct mechanisms, described above as gravitational, gravitational/filtrational (after VSP) and suffosional. The differences between these mechanisms result in different appearances, distribution patterns and onward evolution of the respective forms at the surface, which necessitates different approaches to subsidence hazard assessment. Based on the Ice Mountain example, an attempt is made below to outline possible approaches to such assessment.

\subsection{Hazards imposed by gravitational breakdown}

One of the principal goals of the assessment is to distinguish between areas prone to subsidence (collapse) and those where no karst-induced deformations may occur. Considering dolines formed by the gravitational mechanism in intrastratal karst settings with varying thickness of the overburden, this can be performed by evaluating the critical thickness above which breakdowns cease and therefore cannot reach the surface (Andrejchuk, 1994, 1995, 1999). It was shown above that the question of whether a stoping void can reach the surface or not depends upon the height achieved before a breakdown pile and breakout dome meet during the upward stoping process, in relation to the overburden thickness. This height, the height of closure $\left(h_{c}\right)$, depends on the coefficient of rock loosening $\left(K_{\text {loos }}\right)$ and the initial height of the receptacle cavity $\left(h_{O}\right)$. It can be estimated using a simple formula (Andrejchuk, 1999) accounting for these two factors:

$$
h_{\mathrm{c}}=h_{\mathrm{o}} \frac{K_{\text {loos }}}{K_{\text {loos }-1}}
$$

where:

$h_{c}$ - the height of closure (with reference to the level of the cave floor) of the breakout dome ceiling and the overtaking breakdown pile;

$h_{0}$ - the initial height of the receptacle cavity;

$K_{\text {loos }}-$ coefficient of rock loosening.

For example, the height of closure for the breakdown occurring above a $5 \mathrm{~m}$-high cavity, where the coefficient of loosening is 1.4 , will be $17.5 \mathrm{~m}$. One can show that even in cases of receptacle cavities with relatively large vertical dimensions (5 to $10 \mathrm{~m}$ ) and small $K_{\text {loos }}(1.2$ to 1.4$)$, closure occurs at a height of 30 to $60 \mathrm{~m}$ above the cave floor. 
This explains why no large gravitational collapses occur at the surface above Kungurskaya Cave. They are virtually impossible because of the thickness of overburden commonly exceeding $60 \mathrm{~m}$. Moreover, $K_{\text {loos }}$ is typically $>1.5$ for predominantly slab and block breakdowns in the cave, which decreases the height of closure further. Therefore, gravitational breakdowns do not pose a hazard within the area of the cave field, as migrating voids cannot reach the subsurface ( 5 to $10 \mathrm{~m}$ ) zone.

Using this approach an assessment can be made for the whole area of the Ice Mountain (Fig.14). The starting data are as follows:

- Cave passages occur at a level of 115 to $120 \mathrm{~m}$ asl (a level of $130 \mathrm{~m}$ is adopted, as it results in a more conservative estimate)

- Average height of chambers and master passages is $5 \mathrm{~m}$;

- Coefficient of loosening is 1.3 (minimum).

These data indicate that the level at which typical breakdown structures cease stoping is about 21 to $22 \mathrm{~m}$ above the passages, at an altitude of 151 to $152 \mathrm{~m}$. By taking the $160 \mathrm{~m}$ map contour as marking the upper limit of gravitational breakdown structures, the massif can be divided into two areas. In the area below $160 \mathrm{~m}$ the formation of collapse dolines by gravitational mechanism is possible, and no such dolines can occur in the area above 160m (Fig.14A).

The map shows (compare also with Fig.3A) that the greater part of the Ice Mountain, all of the watershed plateau with altitudes of 180 to $215 \mathrm{~m}$ and the upper parts of slopes, appear to be within the safe zone. The western, gently terraced part and the northern part are slopes of the Sylva and Shakva river valleys, comprising areas prone to collapse due to gravitational breakdown of passage ceilings. The remarkably high density of surface karst features, large dolines in particular, on the western slopes of the Ice Mountain (especially within the area called "Bajdarashki", a kind of a forested karstic badland) is assumed to relate mainly to the intense gravitational destruction of an underlying cave system.

\subsection{Hazards imposed by breakdowns formed after vertical solution pipes}

Within the cave field the exact positions of most of the pipes and breakdown taluses are known from the cave survey. By superimposing the large-scale surface plan on the cave survey the area can be classified according to the probability for new collapses to form by this mechanism. Considering that there could still be unknown pipes and associated breakdown structures, even in close proximity to the mapped passages, the whole cave field area should be treated as potentially hazardous. Locations above pipes and breakdown piles with no visible collapse/subsidence features should be considered as the most hazardous, as well as areas on the continuation of major passages terminated by breakdown, where unknown blind pipes may exist. The potential for re-activation and further growth of pre-existing pipe-related dolines can also be evaluated, based on the predictabilities of their evolution, described above.

Assessment of areas without accessible caves cannot be made in the same way as for the cave field areas. However, the cave field methodology represents a useful model from which some parameters can be derived to help with the evaluation of larger areas displaying similar physiographic and geological conditions. 


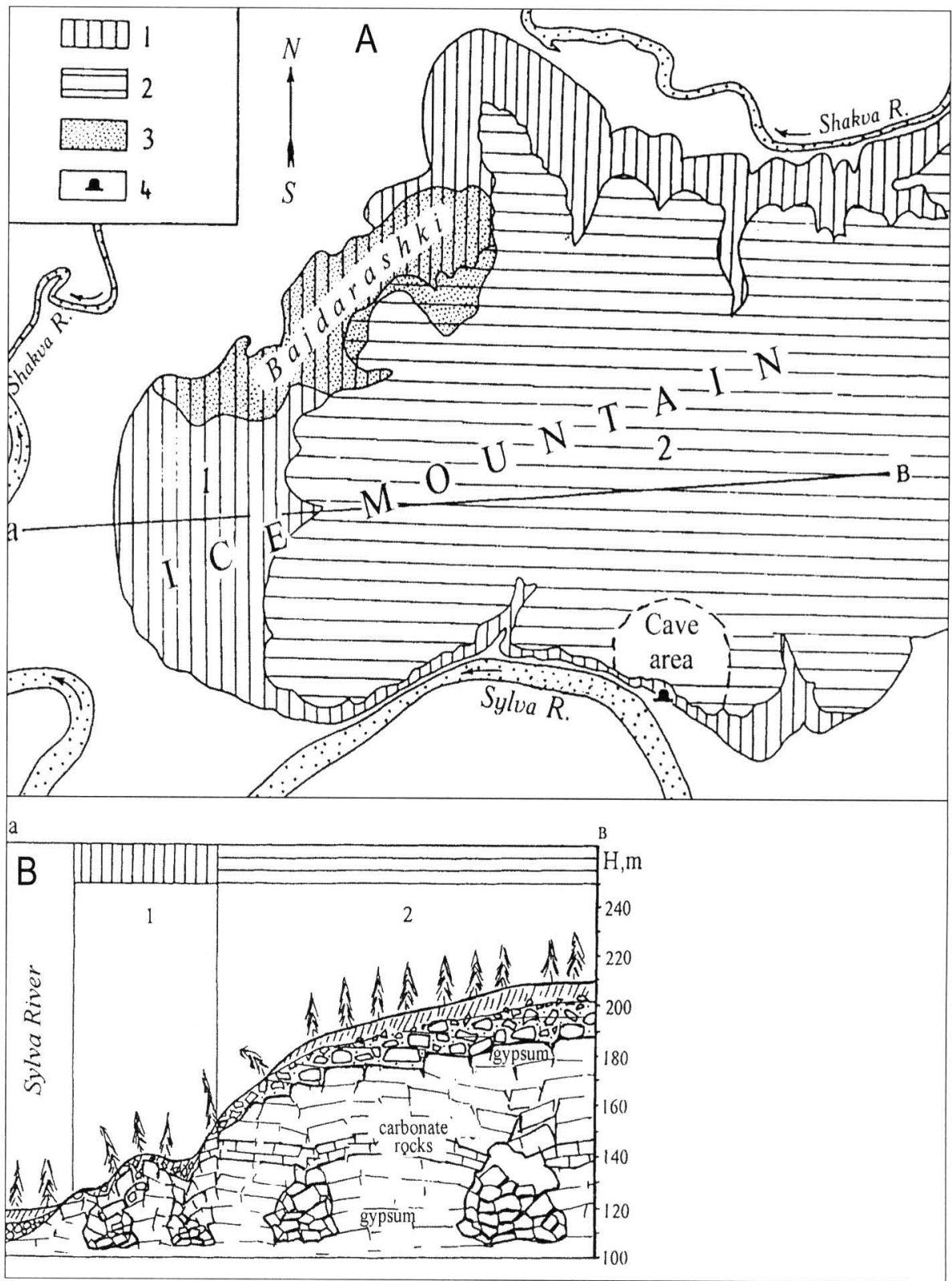

Fig. 14 - Regionalization of the Ice Mountain area according to the conditions of formation of collapse dolines by gravitational mechanism $(A)$ and profile illustrating these conditions $(B) .1=$ the area prone to collapses due to gravitational breakdown of passage ceilings; 2 = the area where no collapse dolines due to gravitational breakdown can occur; 3 $=$ the area with an extremely high density of collapse dolines; 4 = entrance to Kungurskaya Cave. 
The area of the cave field is $0.5 \mathrm{~km}^{2} .80$ dolines in this area are identified as having formed after vertical solution pipes, which suggests an extrapolated density of 160 dolines $/ \mathrm{km}^{2}$. There are 150 mapped pipes, suggesting a density of 300 pipes $/ \mathrm{km}^{2}$. The ratio of the density of this type of doline to the pipe density could be termed the "coefficient of pipe collapse realisation" $=K_{V S P}$. This may be as large as 0.53 , indicating that only slightly more than a half of the existing tubes have so far produced collapse/subsidence features. Hence, almost the same number of new features can be expected to form within the study area in the future. This useful qualitative indication of potential hazard can also be applied to similar areas. For instance, in the central part of the Ice Mountain the observed density of dolines classified as having VSP-related origins is $40 / \mathrm{km}^{2}$, but the prognostic density is $40 / 0.53=75$ dolines $/ \mathrm{km}^{2}$.

Evaluations performed in other areas of the fore-Ural region where observations in caves were possible, suggest that $K_{V S P}$ may vary between 0.3 (highly hazardous areas with respect to new collapses) to 1.0 (areas highly karstified at the surface but rather safe in terms of probability of new collapses). The VSP density parameter, needed for evaluation of $K_{V S P}$, can also be derived from observations in quarries, mines and riverside exposures.

\subsection{Hazards imposed by suffosional dolines}

These dolines are not related to caves in the sulphate rocks, and hence no specific approach for evaluation of the relevant hazard can be derived from speleological observations. They can form almost everywhere where the karst breccia horizon underlies the loose sediment cover, but areas situated at lower elevations than this horizon can be regarded as safe with respect to this type of deformation. Because of their prevailing appearance as gradual subsidences rather than collapse features, and because of their small sizes, dolines of this type present the least hazard among the types considered in this paper.

\section{Conclusions}

Breakdown structures related to the Kungurskaya Cave develop by two mechanisms: gravitational and filtrational/gravitational. The former implies upward stoping of a breakout vault and cessation of the process at some height above the base of the cave, due to its complete filling by fallen clasts. Hence, this mechanism cannot generate surface deformation where the overburden thickness exceeds a certain value. The latter mechanism, stoping of a vault in vertical solution pipes guided by downward percolation, implies that breakdown will almost inevitably express itself at the surface, most commonly as a sudden collapse, even where the overburden thickness is large. Each mechanism results in specific morphologies of dolines and their further evolutionary forms. Subsidence hazard assessment should be performed differently for each type of breakdown.

Deformation and destruction of ceilings due to failure of large unsupported passage spans is more common in the fore-Ural gypsum karst than in the Western Ukraine, because of the dense fissuring and stratification of the sulphate sequence. However, where the overburden thickness is substantial, the main causes of collaps- 
es at the surface are breakdown structures evolved after vertical solution pipes.

Thus, this study suggests (see also Klimchouk and Andrejchuk in this volume) that breakdown formation is not related primarily to large passage spans, and that relatively small forms, indicative of hydrodynamically and speleogenetically "exploited" and "weakened" localities (i.e. vertical solution pipes) are the major cause of deformations at the surface. However, size of passages, though not influencing location and the initial diameter of collapse, does exert guidance, through the cavities' receptacle capacity, over size of mature dolines.

Direct observations in caves, aimed at breakdown characterisation at regional or site-specific levels, are inevitably essential for a more adequate understanding of breakdown mechanisms and assessment of karst subsidence hazard.

\section{Acknowledgement}

The authors sincerely thank Dr. David Lowe of British Geological Survey for improving English in this paper.

\section{REFERENCES}

ANDREJCHUK V.N. 1994. Some peculiarities and consequences of breakdown processes undergroung. Karst Collapses, Abstracts of papers, Ekaterinbourg: 26-30. (russ.).

ANDREJCHUK V.N. 1995. About a possibility of gravitational collapses on the surface of the Ice Mountain above karst cavities. 81-85. In: Kungurskaya Ledjanaja Peshchera, vol.1. Perm University, Perm (russ.).

ANDREJCHUK V.N. 1996. Gypsum karst of the pre-Ural region. 285-292. In: Klimchouk A.B, Lowe D.J, Cooper A.H and Sauro U. (Eds.) - Gypsum karst of the World. Int. Journal of Speleology Theme issue 25 (3-4).

ANDREJCHUK V.N. 1999. Collapses above gypsum labyrinthic caves and stability assessment of karstified terraines. Prut: Chernovtsy. 51 p. (russ.).

ANDREJCHUK V., DOROFEEV E. and LUKIN V. 1997. Organ pipes in carbonate-sulphate rocks at the Kungur Ice Cave, near Perm, Russia. Cave and Karst Science 24 (3): 101-106.

DOROFEEV E.P. 1968. Relations between underground and surface karst forms, on the example of the Kungurskaya Cave. 147-151. In: Proektirovanie, stroitel'stvo i expluatatsija zemljanogo polotna v karstovykh rajonakh. Moscow. (russ.).

DOROFEEV E.P. 1970. The ratio of dimensions of collapse dolines and karst cavities in sulphate rocks. Voprosy Karstovedenia, vol.2, Perm: 11-15 (russ.).

DOROFEEV E.P. 1979. Collapses on the Ice Mountain. Trudy Instituta geologii I geokhimii Uralskogo nauchnogo tsentra AN SSSR, n.140. Perm: 49-53 (russ.).

DOROFEEV E.P. 1987. Failures in the Kungurskaya Cave and measures for the safety of visitation. 35-38. In: Practical utilization of caves of gypsum karst, Perm. (russ.).

DOROFEEV E.P. and ANDREJCHUK V.N. 1990. The Kungurskaya Ice Cave. Perm: 303 p. (russ.).

KLIMCHOUK A.B. and ANDREJCHUK V.N. 1996. Breakdown development in cover beds, and landscape features induced by intrastratal gypsum karst. 127-144. In: Klimchouk A.B, Lowe D.J, Cooper A.H and Sauro U. (Eds.) - Gypsum karst of the World. Int. Journal of Speleology Theme issue 25 (3-4).

KLIMCHOUK A.B. and ROGOZHNIKOV V.YA. 1984. Relations of surface and underground 
karst forms in the conditions of the gypsum karst of the Pridnestrovskaya Podolia. 35-37. In: Inzhenernaja geologija Urala. Perm: 1984.

LUKIN V.S. and EZHOV JU.A. 1975. Karst and construction in the Kungur area. Perm: 120 p. ŠUŠTERŠIČ F. 1973. On the problems of collapse dolinas and allied forms of high Notranjsko (Southcentral Slovenia) (Summary). Geografski vestnik 45: 71-86.

ŠUŠTERŠIČ F. 1974. Some metric problems on the collapse dolinas (Summary). Geografski vestnik 46: $27-46$.

WHITE E. and WHITE W. 2000. Breakdown morphology. 427-429. In: Klimchouk A., Ford D., Palmer A. and Dreybrodt W. (Eds.) -Speleogenesis: Evolution of karst aquifers. Huntsville: Natl. Speleol. Soc. 